\title{
GENETIC AND PHYLOGENETIC VARIATION \\ IN THE DIFFERENT MOLECULAR FORMS \\ OF MAMMALIAN ERYTHROCYTE CARBONIC ANHYDRASES*
}

\author{
Richard E. Tashian, Donald C. Shreffler, $\dagger$ \\ and Thomas B. Shows \\ Department of Human Genetics, \\ University of Michigan Medical School, \\ Ann Arbor, Mich.
}

Mammalian erythrocytes are known to possess either one or two molecular forms of carbonic anhydrase ( $c f$. Tashian; ${ }^{1}$ Armstrong $e t$ al. $;^{2}$ Duff and Coleman; ${ }^{3}$ Nyman and Lindskog; ${ }^{4}$ and Edsall, preceding paper). In the present report, we will compare some genetic and chemical aspects of the presumed homologous forms of red cell carbonic anhydrase from various mammalian species. This type of comparative study gives us an unusual opportunity to analyze the changes that have occurred in two enzyme molecules which have, in all probability, originated by a process of gene duplication (cf. Nyman et al. ${ }^{5}$ ), and have been "evolving" since that time in the same, or a similar, cytoplasmic environment. If this duplication occurred during the evolution of mammals, it might even be possible to locate its approximate phylogenetic position; and, by so doing, determine which of the two molecules represents the original form.

The enzyme forms will be referred to in this paper as carbonic anhydrases I and II (CA I and CA II) which are identical to the designations CA B and CA C, respectively, used by other investigators. ${ }^{2-5}$

\section{EXPERIMENTAL}

The methods used for the purification and assay of the enzymes, tryptic peptide analysis, determination of amino acid composition, and preparation of the electrophoretic patterns, are as described elsewhere ${ }^{6,7}$ unless otherwise specified.

Antisera against the two purified forms of human CA I and CA II were prepared by injecting (intraperitoneally) rabbits with the purified enzymes ( $5.0 \mathrm{mg}$ in $1.0 \mathrm{ml}$ of $10^{-3} \mathrm{M}$ Tris buffer, $\mathrm{pH} 7.5$, and $1.0 \mathrm{ml}$ Freund's adjuvant). The same procedure was followed after two and four weeks, except that on the fourth week $1.0 \mathrm{ml}$ of $0.85 \% \mathrm{NaCl}$ was substituted for Freund's adjuvant, and on the following day, $3.5 \mathrm{mg}$ of enzyme in $1.0 \mathrm{ml}$ saline was injected intravenously. Antiserum was obtained from blood collected on the seventh and ninth

*Supported in part by grant GM-09252 from the National Institutes of Health, U. S. Public Health Service, and U.S.A.E.C. contract AT(11-1)-1552.

†U. S. Public Health Service career development awardee 6-K3-HE-24, 980.

$\ddagger$ U. S. Public Health Service predoctoral trainee 5 TO1 GM-00071-09. 

IN PRIMATE AND RODENT SPECIES

\begin{tabular}{|c|c|c|c|}
\hline \multirow[t]{2}{*}{ Species } & \multirow[t]{2}{*}{$\begin{array}{l}\text { Number } \\
\text { examined }\end{array}$} & \multicolumn{2}{|c|}{$\begin{array}{c}\text { Number } \\
\text { of different } \\
\text { variants }\end{array}$} \\
\hline & & CA I & CA II \\
\hline \multicolumn{4}{|l|}{ Great apes and man } \\
\hline Man (Homo sapiens) & 6,275 & 4 & $0 *$ \\
\hline Chimpanzee (Pan troglodytes) & 92 & 0 & $0 \dagger$ \\
\hline Orangutan (Pongo pygmaeus) & 13 & $2 \ddagger$ & n.t. \\
\hline \multicolumn{4}{|l|}{ Old World primates } \\
\hline Baboon (Papio cynocephalus) & 75 & 17 & 0 \\
\hline Stump-talled macaque (Macaca speciosa) & 11 & 17 & n.t. \\
\hline Rhesus macaque (Macaca mulatta) & 159 & 1 & $1 \ddagger$ \\
\hline Cynomolgus macaque (Macaca irus) & 78 & 2 & 17 \\
\hline Green monkey (Cercopithecus aethiops) & 64 & 0 & 0 \\
\hline \multicolumn{4}{|l|}{ New World primates } \\
\hline Titi monkey (Callicebus cupreus) & 4 & 0 & 1 \\
\hline Splder monkey (Atles belzebuth) & 6 & 1 & 1 \\
\hline Capuchin (Cebus capuchinus) & 3 & 1 & $\mathbf{0}$ \\
\hline \multicolumn{4}{|l|}{ Prosimian primates } \\
\hline Slow loris (Nycticebus coucang) & 5 & 1 & 1 \\
\hline \multicolumn{4}{|l|}{ Rodents } \\
\hline Deer mouse (Peromyscus maniculatus) & 115 & 0 & 0 \\
\hline \multirow[t]{2}{*}{ House mouse (Mus musculus) } & 15 & 0 & 0 \\
\hline & Total & 14 & 5 \\
\hline
\end{tabular}

200 tested

$\dagger_{50}$ tested

Ipolymorphic (frequency $>10 \%$ )

n.t. $=$ not tested 
days after the final injection. Immunodiffusion tests were carried out on agarcoated slides essentially as described by Niswander et al. ${ }^{8}$

\section{Results and Discussion}

\section{Genetic Variation}

Those species in which either proved or assumed genetic variation in electrophoretic patterns have been observed for CA I and CA II are listed in TABLE 1 , as well as species in which more than ten individuals were examined. No variation was observed in 18 other primate species in which fewer than ten animals were tested. Three of the four human CA I variants (CA Ib, CA Ic, and CA Id) have been demonstrated to be under the control of single autosomal genes, ${ }^{9-11}$ and it is highly probable that variations in the homologous enzymes observed in other species are under similar genetic control.

The data in TABLE 1 suggest that there is a tendency for greater electrophoretic variation in CA I than in CA II; a total of 14 distinct variants were found for CA I, and five for CA II. In most species, the variants were either rare or occurred in low frequencies; however, variant types occurring in frequencies greater than ten percent (polymorphic) were found for CA I of orangutan (FIGURE 2), stump-tailed macaque, and baboon, and for CA II of rhesus and cynomolgus macaques (FIGURE 3). Several other species might also fall into this category (e.g., capuchin, spider monkey); however, not enough individuals were examined to be certain. Obviously, only a limited number of individuals and species from one order of mammals were tested; perhaps a different pattern will emerge when more nonprimate species are examined.

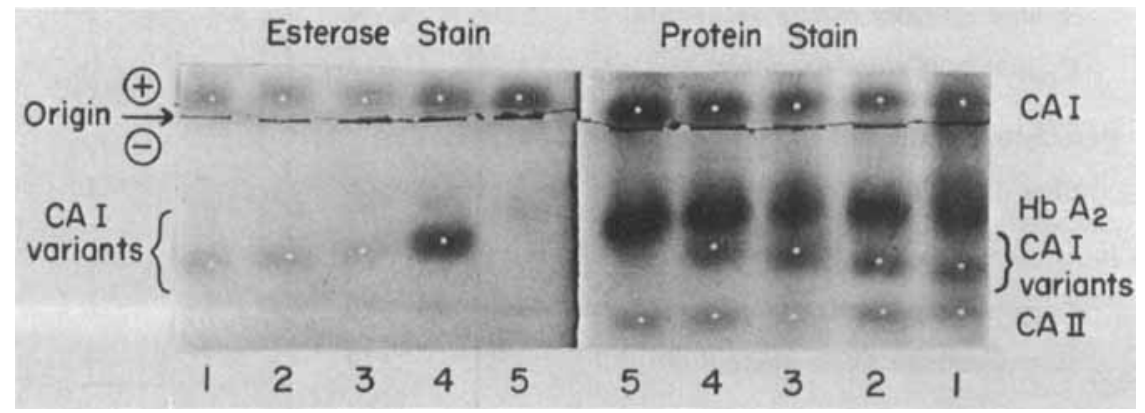

FIGURE 1. Electrophoretic patterns of heterozygous human variants of red cell carbonic anhydrase I (CA I) after esterase and protein staining. CA Ic Guam, 1; CA Ie Michigan, 2; CA Id Michigan, 3; CA Ib Michigan, 4; normal CA I, 5. White dots indicate the carbonic anhydrases. Esterase activity of carbonic anhydrase II (CA II) is too weak to be seen in photograph. Electrophoresis was carried out on a vertical starch gel, $0.02 \mathrm{M}$ borate buffer, $\mathrm{pH} 8.8$, and $0.3 \mathrm{M}$ borate bridge buffer, $\mathrm{pH} 8$ containing $0.03 \mathrm{M} \mathrm{NaCl}$, $17 \mathrm{hr}, 9 \mathrm{v} / \mathrm{cm}, 1-3^{\circ} \mathrm{C}$. Enzyme activity visualized with Blue $R R$ salt as dye coupler and $\beta$-naphthyl acetate as substrate; protein stain is nigrosin. See Reference 7 for details of methodology. 
Some representative, rare, or polymorphic, electrophoretic patterns of both CA I and CA II from various primate species are shown in FIGURES 1-3. In FIGURE 1, both esterase and protein stains of the four human variants of CA I are illustrated. The CA II patterns are not altered in the human hemolysates containing the CA I variants; and alternatively, in the rhesus and cynomolgus hemolysates containing the CA II variants, the CA I patterns are not changed. This genetic evidence supports the already convincing chemical evidence ${ }^{25}$ that these enzymes exist as monomers under the control of separate genetic loci.

\section{Chemical Variation}

Tryptic peptide patterns. In FIGURE 4, the tryptic peptide patterns of CA I are compared from three primate species: man, green monkey (an Old World monkey), spider monkey (a New World monkey), and the deer mouse. It can be seen that although there are many similarities between the patterns of man and the monkeys, they still differ noticeably. As might be expected, the mouse patterns bear little resemblance to the primate patterns. When the tryptic patterns of the other form of red cell carbonic anhydrase, CA II, are compared for the same four species (FIGURE 5), the patterns of man and the two monkeys show remarkably similar patterns, even though man and the spider

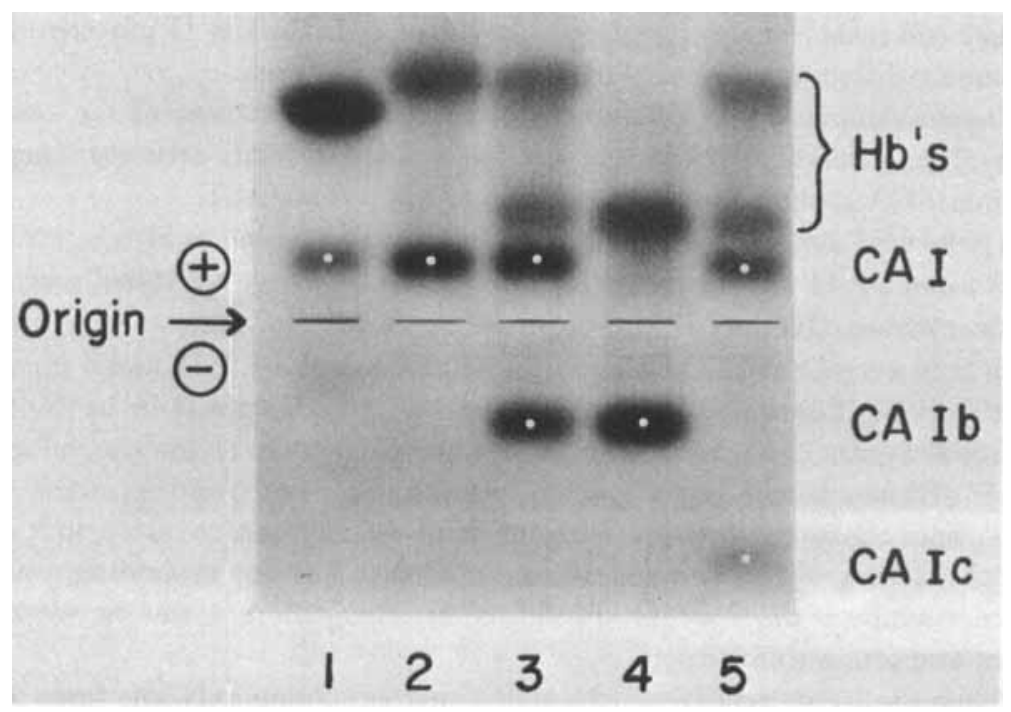

FIGURE 2. Electrophoretic patterns (esterase stain) of carbonic anhydrase I (CA I) variants in orangutan ( $P$. pygmaeus). Human, normal pattern, 1 ; orangutan, normal pattern, 2 ; orangutan, heterozygous ab, 3 ; orangutan, homozygous $\mathrm{b}$ variant, 4 ; orangutan, heterozygous ac, 5 . White dots indicate the carbonic anhydrases; all unmarked bands are normal and variant hemoglobins. Conditions for electrophoresis and staining same as in legend for FIGURE 1. 


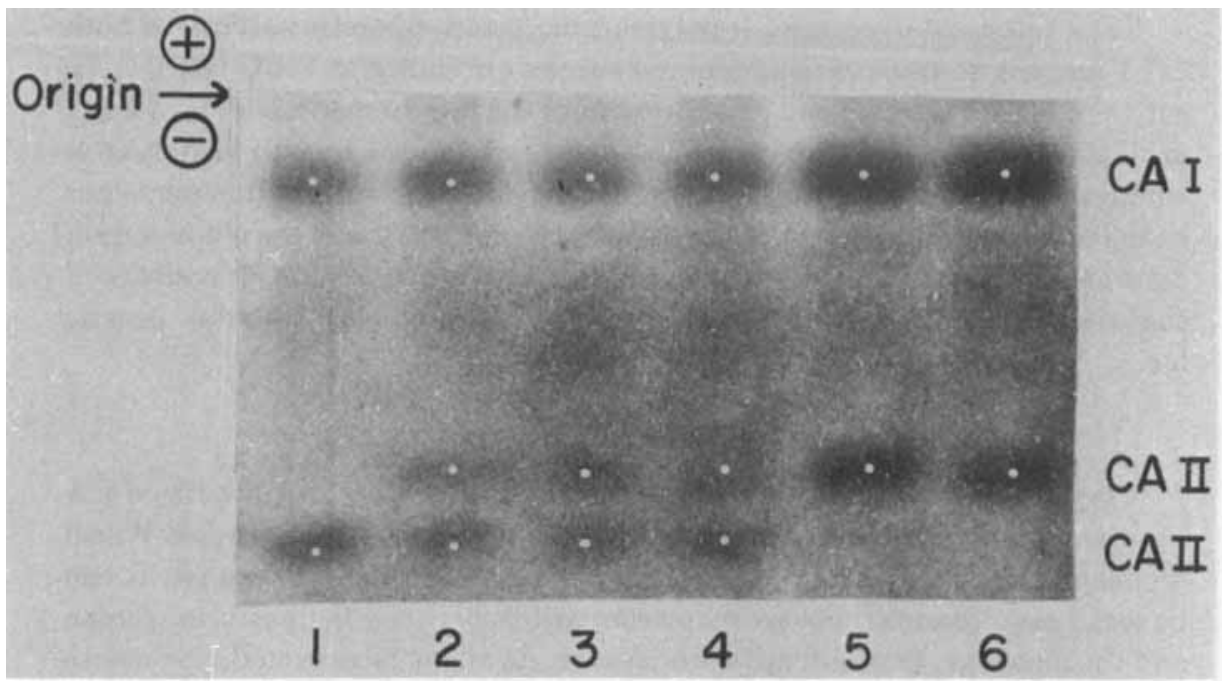

FIGURE 3. Electrophoretic patterns (protein stain) of red cell carbonic anhydrase I (CA II) variants in rhesus ( $M$. mulatta) and cynomolgus $(M$. irus) macaques. Rhesus homozygous CA IIb pattern, 1; rhesus, heterozygous ab, 2,3; cynomolgus, heterozygou ab, 4; rhesus, homozygous CA IIa, 5; cynomolgus, homozygous CA IIa, 6. White dot indicate the carbonic anhydrases. Conditions for electrophoresis and staining same as iv legend for FIGURE 1.

monkey are rather distantly related. As with CA I, the CA II pattern of thi deer mouse differs considerably from the primate patterns.

These similarities and differences in the peptide patterns of the two en zymes from different species bring out the fact that certain structural aspect of primate CA II show less phylogenetic variation than CA I.

Amino acid compositions. In TABLE 2, the total amino acid composition: of CA I and CA II are compared for man, green monkey, pig-tailed macaque and deer mouse. Overall, the compositions of the two enzymes are very similar which is in keeping with the hypothesis that CA I and CA II had a commor genetic origin. There are differences, however, which appear to be constan for each enzyme. This is especially noticeable when we examine the values fo serine, glycine, leucine, and lysine. These amino acid residues show goor interspecies constancy for each enzyme with no apparent overlap in values The similarities of the two mouse enzymes with the corresponding primat enzymes support the concept of the evolutionary homologies between th rodent and primate enzymes.

When the amino acid composition of a species having only one form of re cell carbonic anhydrase is examined (as Nyman and Lindskog ${ }^{4}$ have done fo bovine carbonic anhydrase), the composition shows a higher degree of similar ity with CA II than with CA I of other species. This fact has recently bee: supported by the findings of Nyman et al. ${ }^{5}$ who showed that the sequence 0 the last 19-20 amino acid residues of bovine carbonic anhydrase more closel: 

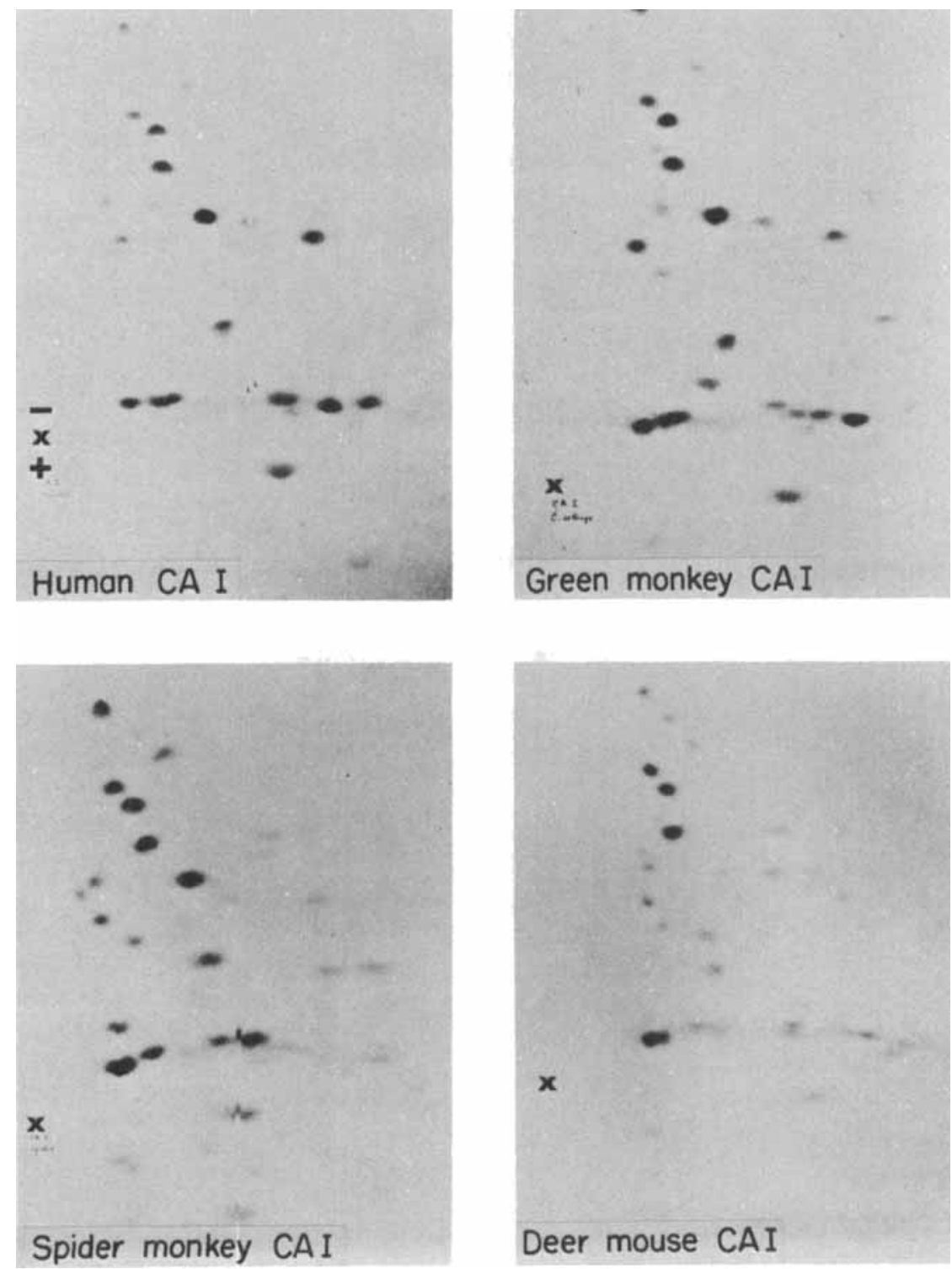

FIGURE 4. Tryptic peptide patterns of red cell carbonic anhydrase I (CA I) from man, green monkey (C. aethiops), spider monkey ( $A$. belzebuth), and the deer mouse ( $P$. maniculatus). See Reference 7 for details of methodology. 

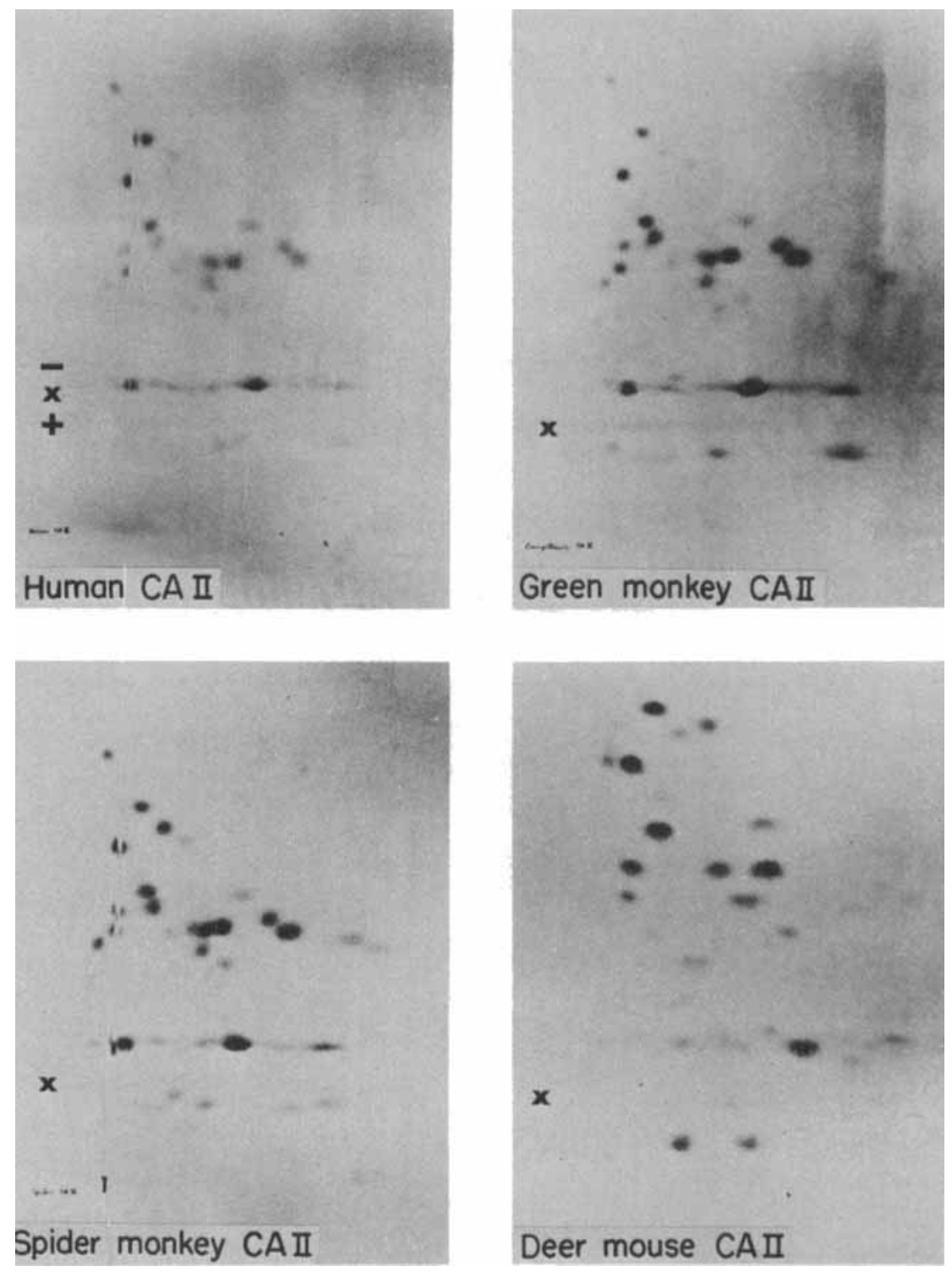

FIGURE 5. Tryptic peptide patterns of red cell carbonic anhydrase II (CA II) from man, green monkey ( $C$. aethiops), spider monkey $(A$. belzebuth), and deer mouse ( $P$. mani culatus). See Reference 7 for details of methodology. 


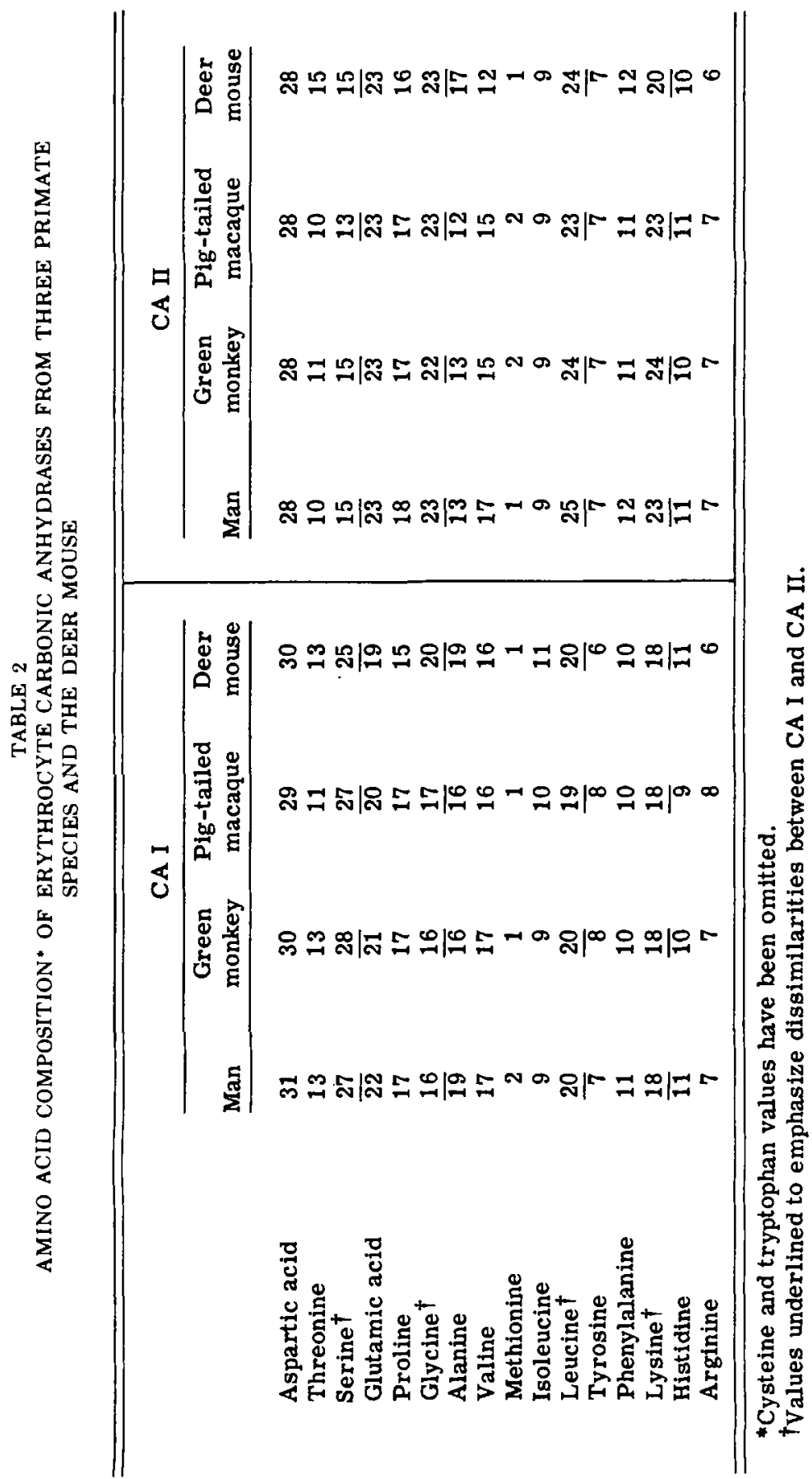


resembles the sequence of human CA II than CA I. In addition, as will be shown later in this report, bovine carbonic anhydrase is also more similar to CA II with respect to its immunochemical properties and specific enzyme activities.

Enzyme activities. More evidence in support of the homologies of the carbonic anhydrase forms is shown in TABLE 3 where the esterase and hydrase

TABLE 3

ESTERASE AND HYDRASE ACTIVITIES OF ERYTHROCYTE CARBONIC ANHYDRASES IN DIFFERENT MAMMALIAN SPECIES

\begin{tabular}{|c|c|c|c|c|}
\hline \multirow[t]{2}{*}{ Species } & \multicolumn{2}{|c|}{$\begin{array}{c}\text { Esterase Activity } \\
\text { units*/mg }\end{array}$} & \multicolumn{2}{|c|}{$\begin{array}{c}\mathrm{CO}_{2} \text { Hydrase } \\
\text { Activity } \\
\text { units } / \mathrm{mg}\end{array}$} \\
\hline & CA I & CA II & CA I & CA II \\
\hline Man (Homo sapiens) & 0.044 & 0.029 & 7.9 & 27.2 \\
\hline Baboon (Papio cynocephalus) & 0.094 & 0.025 & 10.0 & 28.2 \\
\hline Rhesus macaque (Macaca mulatta) & 0.570 & - & 5.7 & 31.0 \\
\hline $\begin{array}{l}\text { Pig-tailed macaque (Macaca } \\
\text { nemestrina) }\end{array}$ & 0.540 & 0.021 & 3.9 & 28.7 \\
\hline $\begin{array}{l}\text { Green monkey (Cercopithecus } \\
\text { aethiops) }\end{array}$ & 0.066 & 0.020 & 7.0 & 30.5 \\
\hline Spider monkey (Ateles belzebuth) & 0.200 & 0.020 & 3.4 & 25.3 \\
\hline $\begin{array}{l}\text { Deer mouse (Peromyscus } \\
\text { maniculatus) }\end{array}$ & 0.048 & 0.020 & 7.1 & 23.0 \\
\hline Ox (Bos taurus) & & $0.010 \ddagger$ & & $17.2 t$ \\
\hline
\end{tabular}

* $\mu$ Moles $\beta$-naphthol formed/minute from $\beta$-naphthyl acetate.

$+\triangle O D$ of Veronal buffer at $276 / \mathrm{m} \mu$ second. See Tashian et al. ${ }^{7}$ for details of enzyme assays.

tValues have been arbitrarily placed under CA $I$ because of presumed homology. See text for explanation.

activities of the purified enzymes from several primate species, deer mouse, and ox are compared. Although considerable interspecies variability exists between the specific esterase activities of CA I, nevertheless, the overall activities show a fairly high degree of correspondence between the rodent and primate enzymes. The ratios between the $\mathrm{CO}_{2}$ hydrase activities of $\mathrm{CA} I$ and CA II do not vary extensively in the species examined. These data also show that when interspecies comparisons are made between the activities of CA I and CA II, there is a greater tendency for variation in the activity of CA I than in CA II. A 13-fold range in esterase activity is seen for CA I, and only a 1.5-fold range for CA II. The higher variability of CA I is not as evident when the hydrase activities of the two forms are compared. 
The activities of the bovine (ox) carbonic anhydrase, present as only one form, ${ }^{4}$ seem to approach the values for CA II rather than CA I of the other species, a finding which is in keeping with the similarities noted above in amino acid compositions and amino acid sequences.

Immunochemical comparisons. Immunodiffusion studies of the carbonic anhydrases from different species, reacted against rabbit anti-human CA I and CA II sera, support the concepts, discussed above, of the relative structural constancy of CA II and the homologies between the primate and rodent enzymes.

The immunodiffusion patterns of purified CA I and CA II of man, pigtailed macaque, green monkey, and deer mouse against rabbit anti-human CA I and CA II sera are shown in FIGURE 6. Although the CA I of the two monkey species gives a reaction of only partial identity with CA I of man, no spurring is detectable when purified CA II preparations from the three species are compared. This is consistent with the observations on the greater constancy of the peptide patterns of CA II (FIGURE 5) discussed earlier.

The immunodiffusion reactions of the Peromyscus maniculatus carbonic anhydrases (FIGURE 6) are of particular interest because both enzyme forms appear to cross-react with both anti-human CA I and CA II sera. The crossreactivity of anti-CA I with $P$. maniculatus CA II has been shown to be due to the presence of a low level of $P$. maniculatus CA I $(<5 \%)$; however, the reaction of anti-CA II with $P$. maniculatus $\mathrm{CA} I$ is a true cross-reaction. Because similar cross-reactivities have been shown for house mouse and flying squirrel (TABLE 4), this may be a general pattern among rodents. This crossreactivity of the different forms of rodent carbonic anhydrases is especially difficult to interpret in view of the facts that their tryptie peptide patterns are dissimilar (FIGURES 3 and 4), and that CA $I$ and CA II of primate species tested to date do not show immunochemical cross-reactivity (cf. Micheli and Buzzi, ${ }^{12}$ and TABLE 4). These immunochemical similarities of the rodent carbonic anhydrases may indicate that certain portions of the two molecules have not diverged as much as the homologous regions of the two primate enzymes.

In TABLE 4 are compared the immunodiffusion reactions against rabbit anti-CA I and anti-CA II sera of (1) the purified carbonic anhydrases, (2) hemolysates absorbed with anti-human CA I or CA II sera, or (3) unabsorbed hemolysates of various mammalian species. Examination of these data reveals several facts. First, it appears that four orders (Primates, Insectivora, Rodentia, and Carnivora) have species with two forms of carbonic anhydrase; obviously, the proposed gene duplication must have taken place before the divergence of these orders. Second, a clue as to which of the two carbonic anhydrases represents the evolutionally older form may be indicated by the fact that when only one form of carbonic anhydrase is present in a species (slow loris, shrew, ox, cat), it seems to correspond most often with CA II. Although the hemolysates of camel and opossum cross-reacted only with anti- 


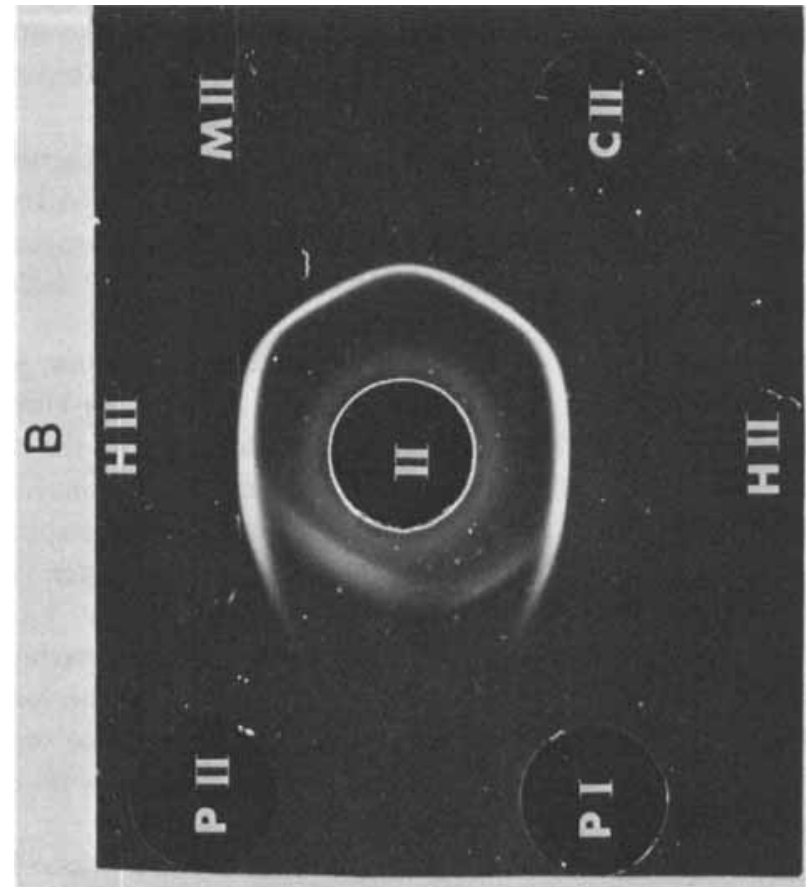

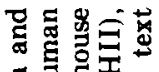

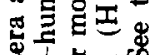

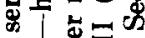

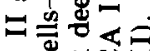
《证园 0 क का

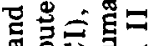

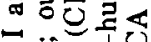

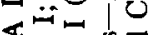

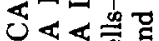
$=00 \%$ \&

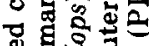

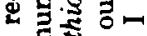
: 政娄 需它《 $+10$

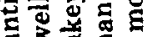

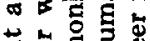

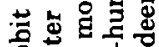

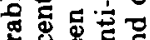
(2) 远 类 害这定 政 을 吨芯造 엉 ๙ 독. ह U일 \& 5 呅

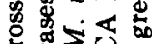
政造 둥

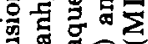
娄

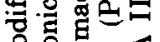
욤口舟

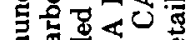
E $E=\stackrel{\leftrightarrows}{5}$ 可

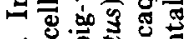
co 0 或

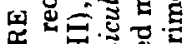
象胥总总 品:

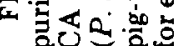


TABLE 4

IMMUNOCHEMICAL REACTIONS OF CARBONIC ANHYURASES FROM DIFFERENT MAMMALIAN SPECIES

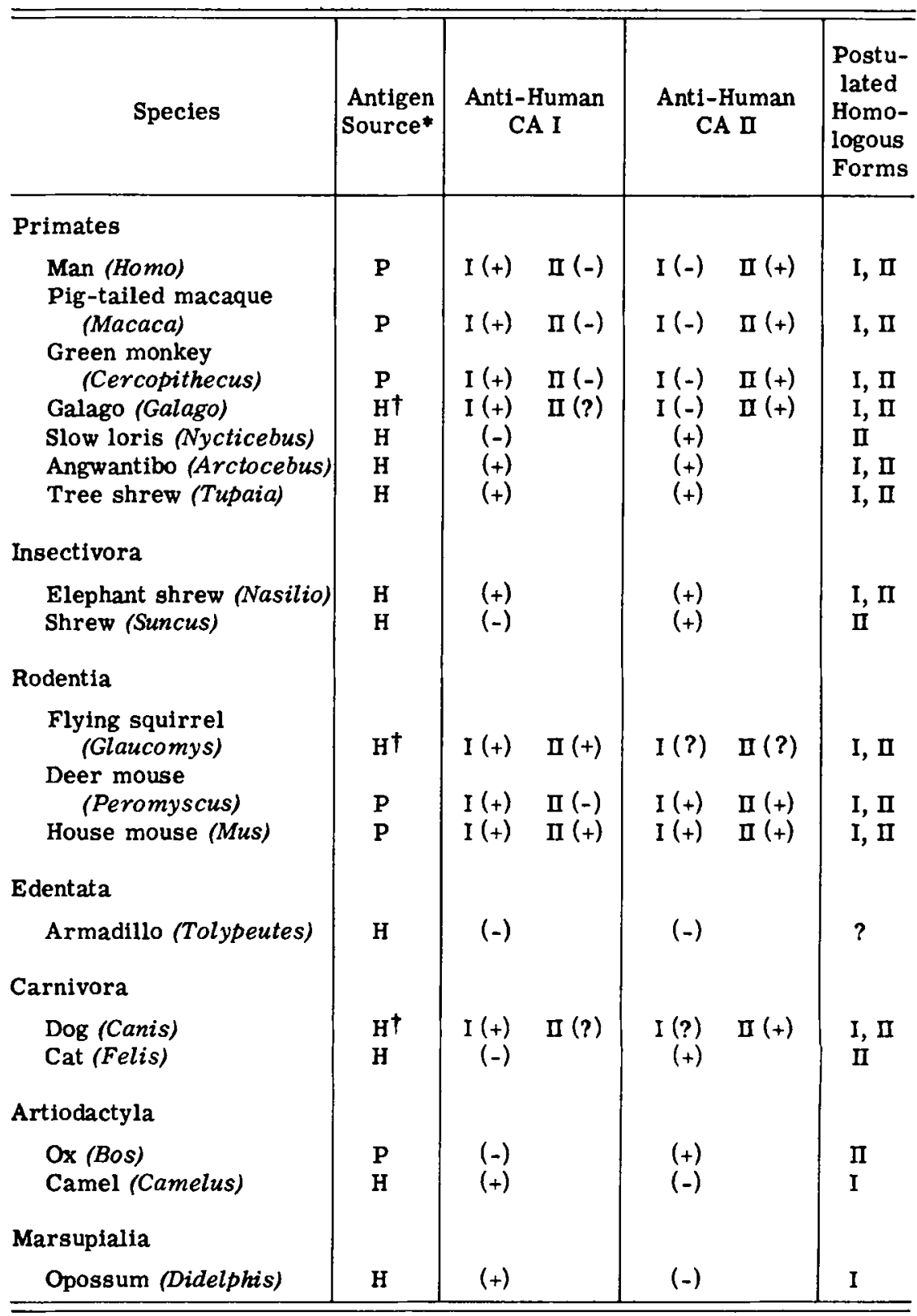

* $\mathbf{P}=$ purffied enzymes; $\mathrm{H}=$ untreated hemolysates; $\mathrm{H} \dagger=$ hemolysates $\mathrm{ab}-$ sorbed with anti-CA I or anti-CA II. 
human CA I serum, such cross-reactivity, where only a single form of carbonic anhydrase is present, may be misleading in view of the cross-reactions observed in rodents. Perhaps, when sequence data are available for these single forms, the homologies will become more evident. Third, it also appears that one or the other of the genes which control the synthesis of the two carbonic anhydrases can either be "turned on and off", or lost, so long as the other remains functional. In most cases, it appears that the cell can get along without CA I more readily than CA II. The fact that CA II has a much higher specific $\mathrm{CO}_{2}$ hydrase activity than CA I (cf. Rickli et al., ${ }^{13}$ and TABLE 2) would seem to indicate that it may be more strongly selected for in this function than CA I. If this is true, then it would follow that the absence of CA I might not seriously upset the physiology of the red cell. This type of reasoning should be approached with caution, however, since at the present time we are quite ignorant of all of the physiological roles of these carbonic anhydrases.

Some evidence in support of the theory that CA II may be the older molecule comes from the work of Shimizu and Matsuura, ${ }^{14}$ who isolated carbonic anhydrase from the red cells of a fish (yellow-fin tuna) and two species of mammals (blue-white dolphin and ox). The fish and mammals had only one form of the enzyme which, among other physicochemical features, showed the high specific hydrase activities characteristic of mammalian CA II rather than the relatively low specific $\mathrm{CO}_{2}$ hydrase activities of $\mathrm{CA} \mathrm{I}$.

\section{SUMMARY}

Two forms of erythrocyte carbonic anhydrase from a number of primate and other mammalian species were compared as to the extent of electrophoretic variability found in the enzymes, as well as several chemical parameters. On the basis of genetic variation, comparative tryptic peptide patterns, immunochemical cross-reactions, and variation in enzyme activities, carbonic anhydrase I appears to show greater variability than carbonic anhydrase II. In the limited number of species examined, wherever only one form of carbonic anhydrase is present, it usually appears to be homologous to form II of species which possess two forms of the enzyme. The possibility that carbonic anhydrase II represents the evolutionally older molecule is discussed.

\section{ACKNOWLEDGMENTS}

The authors are very much indebted to Sharon K. Riggs and Ya-Shiou L. Yu for their skillful execution of the analytical procedures used in this study. We also gratefully acknowledge the kindness of numerous individuals who helped to supply the blood samples.

\section{REFERENCES}

1. TASHIAN, R. E. 1965. Genetic variation and evolution of the carboxylic esterases and carbonic anhydrases of primate erythrocytes. Amer. J. Hum. Genet. 17: $257 \cdot 272$. 
2. ARMSTRONG, J. McD., D. V. MYERS, J. A. VERPOORTE \& J. T. EDSALL. 1966. Purification and properties of human erythrocyte carbonic anhydrases. J. Biol. Chem. 241: 5137-5149.

3. DUFF, T. A. \& J. E. Coleman. 1966. Macaca mulatta carbonic anhydrase. Crystallization and physicochemical and enzymatic properties of two enzymes. Biochemistry 5: 2009-2019.

4. NYMAN, P. O. \& S. LINDSKOG. 1964. Amino acid composition of various forms of bovine and human erythrocyte carbonic anhydrase. Biochim. Biophys. Acta 85: 141-151.

5. NYMAN, P. O., L. STRID \& G. WESTERMARK. 1966. Carboxyl-terminal amino acid sequences of human and bovine erythrocyte carbonic anhydrase. Biochim. Biophys. Acta 122: $554-556$.

6. TASHIAN, R. E. \& M. W. SHAW. 1962. Inheritance of an erythrocyte acetylesterase variant in man. Amer. J. Hum. Genet. 14: 295-300.

7. TASHIAN, R. E., S. K. RIGGS \& Y.-S. L. YU. 1966. Characterization of a mutant human erythrocyte carbonic anhydrase: Carbonic Anhydrase Ic Guam. The amino acid substitution and carboxylesterase and hydratase activities. Arch. Biochem. Biophys. 117: 320-327.

8. NISWANDER, J. D., D. C. SHREFFLER \& J. V. NEEL. 1964. Genetic studies of quantitative variation in a component of human saliva. Ann. Hum. Genet. 27: 319-328.

9. SHAW, C. R., F. N. SYNER \& R. E. TASHIAN. 1962. New genetically determined molecular form of erythrocyte esterase in man. Science 138: 31-32.

10. TASHIAN, R. E., C. C. PLATO \& T. B. SHOWS. 1963. Inherited variant of erythrocyte carbonic anhydrase in Micronesians from Guam and Saipan. Science 140: 53-54.

11. SHOWS, T. B. 1966. The characterization of Carbonic Anhydrase Id Michigan, a human erythrocyte carbonic anhydrase variant. Ph.D. Dissertation. Univ. of Michigan. Ann Arbor, Mich.

12. MICHELI, A.\& C. BUZZI. 1964. Electrophoretic and immuno-electrophoretic studies on the carbonic anhydrase of the human red blood cells. Biochim. Biophys. Acta 89: $324-329$.

13. RICKLI, E. E., S. A.S. GHAZENFAR, B. H. GIBBONS \& J. T. EDSALL. 1964. Carbonic anhydrases from human erythrocytes. J. Biol. Chem. 239: 1065-1078.

14. SHIMIZU, C. \& F. MATSUURA. 1962. Some physico-chemical properties of crystalline carbonic anhydrase from erythrocytes of ox, blue-white dolphin and yellow-fin tuna. Bull. Japanese Soc. Scientific Fisheries 28: 924-929. 